Прегледни чланак

796.06:351.74(497.11)

doi:10.5937/zrpfns54-23518

Bojan D. Janković, Ph.D., Assistant Professor

University of Criminal Investigation and Police Studies, Belgrade

bojan.jankovic@kpu.edu.rs

\title{
THE ROLE OF STEWARDS AT SPORTS EVENTS IN THE REPUBLIC OF SERBIA
}

\begin{abstract}
The traditional view that only the police are responsible for security at sports events has largely been abandoned in the sense that stewards have more important place. This is also recognized in the Serbian legislation, in the standards of the Law on Private Security (LPS), the Law on the Prevention of Violence and Misconduct at Sports Events (LPVMSE), the Law on Public Assembly, and the international regulations of sports federations. The Council of Europe Convention on an Integrated Safety, Security and Service Approach at Football Matches and Other Sports Events - No. 218. (CETS 218), together with the Recommendation REC (2015) 1, and its annexes, which supersedes all previous recommendations, resolutions and statements, has also contributed to defining the role of stewards. Recommendation has become an integral part of the Convention (CETS 218). Common to all the aforementioned regulations is that the stewarding operations can be handled by persons who have completed special training. Unlike international regulations that provide extensive training for stewards, the existing programs in Serbia envisage very few hours of training. The work of stewards would certainly be aided by the improvement of certain legal regulations governing this area. The Republic of Serbia is not yet a signatory to the Convention (CETS 218), and it is necessary for the authorities to accede to its signing and ratification in order for Serbia to adopt the newly established European standards in this field as soon as possible.
\end{abstract}

Keywords: stewards, sports events, the Republic of Serbia

\section{INTRODUCTION}

Hooliganism at sports events in Serbia is a decades-old problem, which has been primarily attempted to be addressed by repressive police action and severe punishment policy, and the public has often criticized this approach for lack of 
results. ${ }^{1}$ Only in recent years in Serbia has it been noted that this problem must be addressed in another way, by applying preventive measures ${ }^{2}$, new proactive police tactics ${ }^{3}$ and engaging other entities in problem solving. First of all, the organizer of the sports event ${ }^{4}$ and stewards, as well as maintaining their cooperation with the police ${ }^{5}$. The traditional view that the police are solely responsible for the security largely leaves in the sense that the private security and stewarding personnel have an increasingly significant place. ${ }^{6}$ Concern for the security of public spaces has become increasingly important over the last thirty years for both the police and private security. ${ }^{7}$ Despite contemporary trends in developed countries, primarily all the opportunities and benefits of cooperation of the police and private security has not been recognized in the Republic of Serbia. ${ }^{8}$

The delegation of the Standing Committee if the Council of Europe on the Prevention of Spectator Violence during a consultative visit to the Republic of Serbia in 2009 found that there was insufficient coordination between various levels of public authority and other persons responsible for preventing violence at sports events. ${ }^{9}$ One of the recommendations to state authorities was of particular importance to the work of stewards, to enact specific laws on security officers and stewards that did not exist in Serbia at the time.

${ }^{1}$ Milojević Saša, Janković Bojan, „Proactive approach of police in combat against football hooliganism“, Archibald Reiss Days, 2011, The Academy of Criminalistic and Police Studies, Belgrade, 737.

${ }^{2}$ See Janković Bojan, „Prevencija nasilja na sportskim priredbama“ [Prevention of violence at sports events], Glasnik prava, 3/2010, 129-154.

${ }^{3}$ Milojević Saša, Mijalković Saša, Janković Bojan, „Determinantna obelezja adolescentnog člana navijačke grupe“ [Determinant features of an adolescent member of a fan group], Teme, 1/2017, 230.

${ }^{4}$ See. Đurđević Nenad, Otašević Božidar, „Obaveza organizatora da prijavi sportsku priredbu“ [Obligation of the organizer to register a sports event], Pravni život, 9/2017, 599-616.

${ }^{5}$ Đurđević Nenad, Otašević Božidar, „Redarska služba na sportskim priredbama“ [Stewarding personnel at sports events], Pravni život, 9/2016, str. 550.

${ }^{6}$ Stajić Ljubomir, Mandić Goran, „Neke kontroverze Zakona o privatnom obezbeđenju“ [Certain controversies of the Law on Private Security], Zbornik radova Pravnog fakulteta, Novi Sad, 2/2014, 132.

${ }^{7}$ Stajić Ljubomir, „Prevencija kriminala sa aspekta dizajniranja javnog prostora i uloge privatnog obezbeđenja“" [Crime prevention in terms of public space design and the role of private security], Zbornik radova Pravnog fakulteta, Novi Sad, 1/2015, 76.

${ }^{8}$ Lončar Zoran, Radivojević Nenad, Radošević Ratko, Mirković Vladan, „Saradnja policije i privatnog obezbeđenja u vanrednim situacijama u Republici Srbiji - stanje i mogućnosti“ [Police and Private Security Cooperation in the Republic of Serbia - State and Opportunities], Zbornik radova Pravnog fakulteta, Novi Sad, 1/2019, 115.

${ }^{9}$ Đurđević Nenad, „Obaveza organizatora sportske priredbe da obrazuje odgovarajuću redarsku službu“ [The obligation of the organizer of a sporting event to form an appropriate stewarding service], Bezbednost, 1/2012, 155. 


\section{LEGAL REGULATIONS OF THE REPUBLIC OF SERBIA REGULATING THE STEWARDING OPERATIONS}

A part of recommendations related to stewarding was adopted in normative acts of the Republic of Serbia, the Law on Private Security (LPS) ${ }^{10}$, The Law on Prevention of Violence and Misconduct at Sports Events (LPVMSE) ${ }^{11}$, the Law on Public Assembly ${ }^{12}$, as well as by-laws.

The obligation of the organizer to establish the stewarding service at sports events stems from the norms of the Law on Public Assembly (Art. 11, Par. 1, item 1) stating that the organizer is obliged to engage the stewarding service, but it neither stipulates how this should be done, nor stipulates powers of stewards. A similar obligation is stated in the provisions of the LPVMSE, where the organizer of a sports event is obliged to establish appropriate stewarding personnel or to hire a legal person or entrepreneur to perform physical security tasks and maintain order at a sports event (Art. 8 Par. 1). In the case of international sports events, high-risk sports events or sports events of the highest rank of national team sports competitions, the organizer is obliged to engage a legal person or entrepreneur to do the business of private security for the performance of stewarding activities (Art. 8 Par. 2). The difference between these sports events is that in the first case, the organizer of a sports event may set up the stewarding personnel from natural persons who have a Stewards Licence in accordance with the LPS (Art. 11 Par. 2) and legal entities and entrepreneurs who hold a Licence to conduct the business of physical and technical protection without weapons (Art. 9 Par. 1 item 2). In the second case, due to the importance of sports competitions, risk assessment, the number of spectators, etc., only a legal entity or an entrepreneur can be hired for these jobs. This attitude is also confirmed in the provision of Art. 40 Par. 1 of the LPS, which states that legal entities and entrepreneurs for private security can perform order maintenance jobs at sports events, while exceptional order maintenance can be performed only by stewards at school events and certain sports events when a peaceful assembly can be ensured in this way. When stewarding is formed by a legal person or an entrepreneur, then for every three employees of the security service in the stewarding personnel, additional 10 licenced security officers or stewards may be hired temporarily (Art. 40 Par. 4). An additional explanation regarding stewards should be given here. Namely, the latest amendments to the LPS (Art. 8 Par. 2) provide that stewarding may be performed by natural persons holding a Stewarding Licence issued by the Ministry of Interior (MoI). The same amendment defines that a steward is a natural person who is

${ }^{10}$ Official Gazette of the RS, No. 104/2013-8, 42/2015-3, 87/2018-31.

${ }^{11}$ Official Gazette of the RS, No. 67/2003-1, 101/2005-28 (state law), 90/2007-10, 72/2009-53 (state law), 111/2009-48, 104/2013-8 (state law), 87/2018-23.

12 Official Gazette of the RS, No. 6/2016. 
trained to perform stewarding operations, who holds a MoI licence to carry out these duties, and to which the provisions of the LPS relating to private security officers apply accordingly (Art. 3, Par. 1, item 15).

The duties and powers of stewarding personnel at sports events are determined by the LPS and LPVMSE. The first law stipulates that security officers and stewards carry out stewarding without weapons (Art. 40 Par. 3). Here again it should be emphasized that the security service can be performed by security officers, if a legal entity or entrepreneur is involved in securing a sports event, and in the other case, a natural person or a steward may be hired. The earlier provisions of the LPS did not specify the special powers of stewards, but they were in line with the powers of security officers during the exercise of physical protection without weapons. Recent amendments to the LPS have found that stewards cannot use gas spray, restraints and handcuffs, specially trained dogs and firearms (Art. 46 Par. 7). Accordingly, the steward is authorized to: 1) issue a warning or order to a person or prohibit a person from entering and staying in a protected facility; 2) check the identity of the person; 3) stop and inspect the person, objects or means of transport; 4) temporarily seize items; 5) temporarily detain a person; 6) and to use only physical force as a coercive means (Art. 46). When a legal person or entrepreneur is hired to secure a sports event, the security officer may exercise the same powers as the steward and also additional coercive means restraints and handcuffs and the gas spray (Art. 46 Par. 1 item 6). The Ordinance on the Use of Coercive Means in the Performance of Private Security Operations ${ }^{13}$ provides that a security officer may use coercive means only when necessary and in proportion to the resistance or attack provided by another person, in order to achieve lawful objectives, in the manner and under the conditions prescribed by the LPS and the aforementioned Ordinance, so that the task is performed with the least detrimental effect on the person against whom that force is used (Art. 2).

However, in accordance with the provisions of the LPS, in the concluded security contract, i.e. on the performance of stewarding activities, which the legal entity and the entrepreneur in the field of private security concludes with the user of the service, the contractual powers are specified (Art. 46 Par. 3). In any case, the contracted powers may not exceed the legal framework, that is, they may be either the same or smaller than the legal powers.

Stewards who perform activities during sports events act not only in accordance with the provisions of the LPS but also with other laws. Thus, the provisions of the LPVMSE (Art. 8a) prescribe duties of stewards at a sports event. Stewards are obliged to: 1) prohibit access to the venue where the sports event is held to persons under the influence of alcohol or other narcotic substances, or from their conduct it may be inferred that they are prone to violence or misconduct; 2) separate the

${ }^{13}$ Official Gazette of the RS, No. 30/2015. 
visiting fans by directing them to the specific entrances and exits of the sports facility and the special part of the sitting area designated for them; 3) ensure that the spectator is seated in a specific place; 4) prevent the spectators from entering the sports field and prevent their transition from one part of the sitting area intended for fans of one club to another; 5) prevent the introduction or sale of alcoholic beverages in a sports facility; 6) prevent the introduction of items that can be used in violent acts (pyrotechnics, poles, bottles, etc.), or which may interfere with the course of the sports event (mirrors, laser pointers, high-power sound devices), banners or signs by which racial, religious, national or other intolerance and hatred is encouraged, that is, the content of which is offensive or obscene, etc. into the sports facility; 7) prevent the introduction and featuring the fan symbols that are larger in size and may interfere with the work of officials, except flags, scarves, hats and jerseys with club features into the sports facility; 8) warn or send out the spectator who by his / her behaviour or omission of a certain action may cause violence at a sports event, endanger the safety of participants of a sports event or interfere with its flow. There may be a problem with the application of the aforementioned powers because they are not sufficiently clearly defined, nor the procedures for their implementation are determined. In case of the first aforementioned authorization, a question may already been asked: how will stewards determine if a particular fan is under the influence of alcohol or other intoxicants? What is the allowable concentration of alcohol in blood with which a fan is allowed to enter the stadium? When relying on the subjective judgment of stewards in identifying persons under the influence of alcohol is in question, the most obvious disadvantage of this aspect of the applicable regulations lies in the fact that not all stewards are equally able or willing to recognize the different signs of intoxication in persons consuming alcohol. ${ }^{14}$ In contrast to Serbia, e.g. in the Republic of Croatia, stewards have been authorized by the Amendments to the Law on Prevention of Riots at sports events from 2009 and 2011 to determine the presence of alcohol in the body, i.e. to prohibit access to a sport facility to a person in a state of intoxication..$^{15}$ The lower limit for alcohol was initially set at $0.8 \%$ in the body, and in 2011, it was lowered to $0.5 \%$.

When a legal entity or an entrepreneur is hired to secure a sports event, according to the LPS, security officers must be in uniform during the execution of stewarding activities and be provided with uniform jackets or vests with light reflective straps and the words "Security" in Serbian and English, while hired stewards are required to wear vests with light reflective straps and the inscription

${ }_{14}$ Šuvalija Mustafa, Pustahija Almir, „Uvođenje testiranja koncentracije alkohola u krvi kao korak ka unapređenju prevencije nasilnog ponašanja posjetilaca sportskih takmičenja u Bosni i Hercegovini" [Introducing blood alcohol testing as a step towards improving the prevention of violent behavior in sports competitions in Bosnia and Herzegovina], Kriminalističke teme, 1-2/2015, 68.

${ }^{15}$ Ibid 69. 
"Steward" in Serbian and English (Art. 42). While performing stewarding activities, the security officer and the steward are not allowed to regulate traffic outside the boundaries of the protected area.

Pursuant to provisions of the LPS (Art. 41), when a legal entity and a private security entrepreneur provides the security service, that is, when a public meeting organizer organizes a stewarding personnel, if he hires more than ten security officers or stewards, he is required to draw up a security plan, which the organizer, together with the application or notification, delivers to the competent police station in the territory where the sports event is held. The law amended an earlier ruling that stipulates the plan to have an obligation to specify the powers that stewards can apply, which the professional public did not agree with, ${ }^{16}$ because the Law has already defined them. Also, unlike the previous legal solution where there was an obligation to make a plan only if a legal entity or an entrepreneur was involved in the security, there is also an obligation to create the plan for the organizer who establishes stewarding activities provided by stewards. LPVMSE and the Law on Public Assembly do not contain an explicit obligation for the organizers of a sports event to have a written security plan. However, as an obligation, it may exist in sports associations' regulations. The problem is that such an obligation exists exclusively in the Rulebook on safety and security at football matches of the Football Association of Serbia ${ }^{17}$ within the obligation to have a plan of preventive action of the home club. ${ }^{18}$

A prerequisite for the proper performance of stewarding activities at sports events is the completion of training for these jobs. The training program for security officers, who can perform stewarding activity, as well as stewards themselves, is prescribed by the Rulebook on Programs and Methods of Conducting Professional Training for Private Security and Stewards ${ }^{19}$. Unlike the previous Regulations, there are now two programs in addition to the Regulations: Annex 2 - Physical and Technical Protection Training Program and Annex 3 - Stewarding Activities Program. The stewarding activities program provides a total of 28 hours of theoretical and practical training $(11+17)$, with five topics: 1 . Regulations in the field of public assembly, 2. Powers of the steward, 3. First Aid, 4. Emergency and Evacuation, and 5. Training in the Deployment of Physical Forces and Self-Defence Techniques. Interestingly, there is no specific topic related to stewards' duties at sports events. Only the first topic (Regulations in the field of public assembly),

${ }^{16}$ Stajić Ljubomir, Mandić Goran, „Neke kontroverze Zakona o privatnom obezbeđenju“ [Certain controversy concerning the Law on private security], Zbornik radova Pravnog fakulteta, Novi Sad, 2/2014, 138.

${ }^{17}$ Official Gazette of the FAS, No. 1/2007.

${ }^{18}$ Đurđević Nenad, Otašević Božidar, „Redarska služba na sportskim priredbama“ [Stewarding personnel at sports events], Pravni život, 9/2016, 560.

${ }^{19}$ Official Gazette of the RS, No. 15/2019. 
which is scheduled for a total of 2 hours of lectures, among other numerous titles, mentions measures to prevent violence and misbehaviour at sports events, duties of organizers and stewards at sports events. The range of topics for the training of security officers is broader, as is the number of hours (90), but the number of hours related to the security of public gatherings is also very small. The topic covered by officers is under number 4 - Securing Public Assembly (Jobs and duties of stewards at public gatherings, Special duties of stewards at sports gatherings, Security plan: drafting, form and content of the plan) and is scheduled for a total of 6 hours.

Taking into account all the specificities and complexities of securing sports events, especially those at risk of violence and misconduct of participants, it is more than a modest training program to be mastered by persons who will be engaged as stewards at sports events. Practically, the maximum of 2 hours can be devoted to stewarding at sports events.

\section{INTERNATIONAL REGULATION RELATING TO STEWARDING OPERATIONS}

The year of 1985 can be taken as the beginning of a new approach to confront the problem of hooliganism at sports events and the problem of fan violence in Europe, when the European Convention on Spectator Violence and Misbehaviour at Sports Events and in particular at Football Matches was adopted ${ }^{20}$. Since its adoption, various recommendations, resolutions and statements have been made that also relate to a new approach to the problem. However, the current Convention could not be the basis for facing the new challenges that have arisen since its enactment. Therefore, in 2013, the Committee of Ministers of the Council of Europe decided not to update the existing Convention, but to draft a completely new document and asked the Standing Committee to start drafting a new Convention. ${ }^{21}$ The Standing Committee unanimously adopted the draft text of the Convention in December 2014. Following that date, it was upgraded with best practice examples for the past 30 years, and finally on $3^{\text {rd }}$ July 2016, it was opened for signature at the stadium in Saint-Denis, near Paris, during EURO 2016 in France. The Convention entered into force on $1^{\text {st }}$ November 2017 after ratification by three States (France, Monaco and Poland). It is called the Council of Europe Convention

${ }^{20}$ Law Ratifying the European Convention on the Violence and Misconduct of Spectators at Sports Events, Especially at Football Matches, Official Gazette of SFRY-MP, No. 9/1990-15.

${ }^{21}$ Primorac Damir, Pilić Marko, ,Sigurnost i zaštita na nogometnim utakmicama i ostalim sportskim priredbama prema rješenjima Vijeća Europe No. 218“ [Security and protection at football matches and other sports events according to Council of Europe decisions No 2018], Zbornik radova Pravnog fakulteta u Splitu, 2/2019, 405. 
on an Integrated Safety, Security and Service Approach at Football Matches and Other Sports Events (CETS 218) 22 .

In addition to the adoption of the Convention (CETS 218), the Standing Committee noted that earlier recommendations were at odds with the current situation on the ground, and in 2015 adopted a new Recommendation REC (2015) $1^{23}$, replacing all previous recommendations, resolutions and statements adopted by the Standing Committee by that date. The recommendation became an integral part of the Convention (CETS 218). In addition to the main text of the Recommendation, it also contains the accompanying schedules, annexes of recommended good practice A - Safety ${ }^{24}$, B - Security ${ }^{25}$ and C - Service ${ }^{26}$. Of particular interest is the annex A - Safety, which contains Chapter 41 that relates to the work of stewards.

The term used in Annex A for stewarding at sports events is "Steward", partly for ease of reference, but primarily because the term reflects good European practice and is widespread and accepted in the LPS of the Republic of Serbia (Art. 42). Annex A stipulates the basic duties of a steward, depending on the size and configuration of the sporting facility, and the nature of the sports event, but in principle, the stewards should:

- understand their overall responsibility for the health and safety of all spectators, other stewards, stadium staff, participants and themselves;

- carry out security checks;

- control or direct spectators entering or leaving the playground to help ensure a steady flow of people to and from the viewing area;

- assist in the safe running of a sports event rather than watching the event;

- control entrances, exits, and other strategic points; e.g., fan separation points, exit doors or gates;

- monitor the dynamics of the gathering to ensure the safe allocation of spectators and the prevention of overcrowding, especially in the stands;

- provide assistance to emergency services (police, firefighters, ambulances) if necessary;

${ }^{22}$ Council of Europe Convention on an Integrated Safety, Security and Service Approach at Football Matches and Other Sports Events, Council of Europe Treaty Series - No. 218.

${ }^{23}$ Recommendation Rec (2015) 1 of the Standing Committee on Safety, Security and Service at Football Matches and other Sports Events.

${ }^{24}$ Recommendation Rec (2015) 1 of the Standing Committee on Safety, Security and Service at Football Matches and other Sports Events - ANNEX A on Safety - Recommended Good Practices.

${ }^{25}$ Recommendation Rec (2015) 1 of the Standing Committee on Safety, Security and Service at Football Matches and other Sports Events - ANNEX B on Security - Recommended Good Practices.

${ }^{26}$ Recommendation Rec (2015) 1 of the Standing Committee on Safety, Security and Service at Football Matches and other Sports Events - ANNEX C on Service - Recommended Good Practices. 
- provide emergency first aid;

- respond to emergencies (such as early stages of fire); activate the alarm and take other necessary emergency actions;

- in an emergency, undertake certain duties on their own initiative or upon the instructions of a security officer or an appropriate emergency officer;

- be a contact person for fans, including in cases of discriminatory behaviour by other viewers;

- actively participate in services and strategies of good club hospitality and event management. ${ }^{27}$

Annex A specifically emphasizes that steward training should be conducted by professional, competent individuals or organizations. No steward should be deployed at the stadium until all aspects of relevant familiarization and introductory training have been undertaken. Stewards should not work unaccompanied until they demonstrate that they understand the functions of a steward in organizing events; pass four events as stewards and during them are judged whether they are able to handle accidents and emergencies and control the entry, exit and movement of people in the stadium. All training and assessment records should be complete and fully maintained to ensure that training and assessments can be checked as needed.

Upon completion of the training, the steward should have acquired knowledge and competencies in the following areas:

- the role and responsibility of the steward;

- Stewart Code of Conduct;

- the rules of the stadium and the code of conduct for spectators and prohibited articles;

- the legal rights and powers of the steward;

- search techniques;

- ticket identification and accreditation, anti-forgery checks;

- conflict management and resolution;

- arrest and / or detention (in accordance with national laws and regulations);

- throwing out of the stadium procedures;

- identifying and acting against any discriminatory behaviour, symbols and chanting;

- giving first aid;

- the basis of firefighting and fire response;

- dynamics and mass management;

${ }^{27}$ See Recommendation Rec (2015) 1 of the Standing Committee on Safety, Security and Service at Football Matches and other Sports Events - ANNEX A on Safety - Recommended Good Practices. 
- use of CCTV;

- communication;

- stadium contingency plans and the role of the steward in an emergency. ${ }^{28}$

In addition to conventions adopted by interstate organizations, international sources of law in the field of sport are represented by numerous general legal acts of international sports organizations. ${ }^{29}$ It is especially important that, in addition to national legal solutions, members of the stewarding personnel know the rules of sports associations, which regulate safety at sports events in more detail. The grand international sports federations have also, through special ordinances, regulated the issues of securing sports events, in which the largest part is devoted to the work of stewards. The importance of "good" sports rules is the best example of FIFA and UEFA rules, which have been partially transposed into the sports rules of the Football Association of Serbia. Thus, FIFA ${ }^{30}$ stipulates that a steward must be a person over 18 years of age with the formal stewards' training completed.

\section{CONCLUSION}

This paper discusses national and international regulations governing stewarding operations. Common to all the above-mentioned regulations, both national and international, is that persons who have completed specific training can perform the stewarding operations. However, unlike international regulations that provide extensive training for stewards, the existing programs in Serbia provide very few classes for topics related to stewarding at sports events. Observing modern sports events, especially the top ones, we can conclude that the standards for their security have been raised very high. This requires substantial, intensive and comprehensive stewards' training. Stewarding activities would certainly be helped by the improvement of certain legal regulations governing sports safety. In recent years, good steps have certainly been made by the adoption of legal solutions related to the prevention of violence at sports events, but this should not end here, the existing regulations should be improved in accordance with the situation in the field. It can be observed in particular that there is no code of conduct for stewards, which should be adopted as soon as possible, as in Recommendation REC (2015) and its accom-

\footnotetext{
${ }^{28}$ See Recommendation Rec (2015) 1 of the Standing Committee on Safety, Security and Service at Football Matches and other Sports Events - ANNEX A on Safety - Recommended Good Practices.

${ }^{29}$ Šuput Dejan, „Propisi FIFA i UEFA protiv nasilja na fudbalskim utakmicama - problem preklapanja nadležnosti države i sportskih organizacija“" [FIFA and UEFA regulations against violence at football matches - the problem of overlapping competencies between the state and sports organizations], Bezbednost,1/2012, 167.

${ }^{30}$ FIFA, FIFA Stadium Safety and Security Regulations, Zurich 2013, 26.
} 
panying annexes. The Republic of Serbia has not signed the Convention (CETS 218) and its annexes that make recommendations for the improvement of the work of all services dealing with this problem, including the stewarding personnel yet. It is necessary for the authorities to accede to the signing and ratification of the Convention (CETS 218) in order for Serbia to adopt the newly established European standards in this field as soon as possible.

\section{REFERENCES}

Council of Europe Convention on an Integrated Safety, Security and Service Approach at Football Matches and Other Sports Events, Council of Europe Treaty Series - No. 218.

Council Resolution concerning an updated handbook with recommendations for international police cooperation and measures to prevent and control violence and disturbances in connection with football matches with an international dimension, in which at least one Member State is involved ('EU Football Handbook'), Official Journal of the European Union C 444/1, 29.11.2016.

Đurđević Nenad, „Obaveza organizatora sportske priredbe da obrazuje odgovarajuću redarsku službu" [The obligation of the organizer of a sporting event to form an appropriate stewarding service], Bezbednost, 1/2012, 146-165.

Đurđević Nenad, Otašević Božidar, „Redarska služba na sportskim priredbama” [Stewards at sports events], Pravni život, 9/2016, 549-564.

Đurđević Nenad, Otašević Božidar, „Obaveza organizatora da prijavi sportsku priredbu” [Obligation of the organizer to register a sports event], Pravni život, 9/2017, 599-616.

FIFA, FIFA Stadium Safety and Security Regulations, Zurich 2013.

Janković Bojan, „Prevencija nasilja sportskim priredbama” [Prevention of violence at sports events], Glasnik prava, 3/2010, 129-154.

Law on Prevention of Violence and Misconduct at Sports Events, Official Gazette of the RS, No. 67/2003-1, 101/2005-28 (state law), 90/2007-10, 72/2009-53 (state law), 111/2009-48, 104/2013-8 (state law), 87/2018-23.

Law on Private Security, Official Gazette of the RS, No. 104/2013-8, 42/2015-3, 87/2018-31.

Law on Public Assembly, Official Gazette of the RS, No. 6/2016.

Law Ratifying the European Convention on the Violence and Misconduct of Spectators at Sports Events, Especially at Football Matches, Official Gazette of SFRY-MP, No. 9/1990-15.

Lončar Zoran, Radivojević Nenad, Radošević Ratko, Mirković Vladan, „Saradnja policije i privatnog obezbeđenja u vanrednim situacijama u Republici Srbiji stanje i mogućnosti" [Police and Private Security Cooperation in the Republic of Serbia - State and Opportunities], Zbornik radova Pravnog fakulteta, Novi Sad, 1/2019, 113-151.

Milojević Saša, Janković Bojan, „Proactive approach of police in combat against football hooliganism", Archibald Reiss Days, 2011, The Academy of Criminalistic and Police Studies, Belgrade, 737-749. 
Milojević Saša, Mijalković Saša, Janković Bojan, „Determinantna obeležja adolescentnog člana navijačke grupe" [Determinant features of an adolescent member of a fan group], Teme, 1/2017, 227-241.

Primorac Damir, Pilić Marko, „Sigurnost i zaštita na nogometnim utakmicama i ostalim sportskim priredbama prema rješenjima Vijeća Europe br. 218” [Security and protection at football matches and other sports events according to Council of Europe decisions No 2018], Zbornik radova Pravnog fakulteta u Splitu, 2/2019, 401- 419.

Recommendation Rec (2015) 1 of the Standing Committee on Safety, Security and Service at Football Matches and other Sports Events.

Recommendation Rec (2015) 1 of the Standing Committee on Safety, Security and Service at Football Matches and other Sports Events - ANNEX A on Safety Recommended Good Practices.

Recommendation Rec (2015) 1 of the Standing Committee on Safety, Security and Service at Football Matches and other Sports Events - ANNEX B on Security - Recommended Good Practices.

Recommendation Rec (2015) 1 of the Standing Committee on Safety, Security and Service at Football Matches and other Sports Events - ANNEX C on Service - Recommended Good Practices.

Rulebook on safety and security at football matches of the Football Association of Serbia, Official Gazette of the FAS, No. 1/2007.

Rulebook on Programs and Methods of Conducting Professional Training for Private Security and Stewards, Official Gazette of the RS, No. 15/2019.

Rulebook on the Use of Coercive Means in the Performance of Private Security Operations, Official Gazette of the RS, No. 30/2015.

Stajić Ljubomir, „Prevencija kriminala sa aspekta dizajniranja javnog prostora i uloge privatnog obezbeđenja" [Crime prevention in terms of public space design and the role of private security], Zbornik radova Pravnog fakulteta, Novi Sad, 1/2015, 75-87.

Stajić Ljubomir, Mandić Goran, „Neke kontroverze Zakona o privatnom obezbeđenju” [Certain controversies of the Law on Private Security], Zbornik radova Pravnog fakulteta, Novi Sad, 2/2014, 131-150.

Šuput Dejan, „Propisi FIFA i UEFA protiv nasilja na fudbalskim utakmicama - problem preklapanja nadležnosti države i sportskih organizacija" [FIFA and UEFA regulations against violence at football matches - the problem of overlapping competencies between the state and sports organizations], Bezbednost,1/2012, 166-179.

Šuvalija Mustafa, Pustahija Almir, „Uvođenje testiranja koncetracije alkohola u krvi kao korak ka unapređenju prevencije nasilnog ponašanja posjetilaca sportskih takmičenja u Bosni i Hercegovini” [Introducing blood alcohol testing as a step towards improving the prevention of violent behavior in sports competitions in Bosnia and Herzegovina], Kriminalističke teme, 1-2/2015, 63-74. 
Др Бојан Д. Јанковић, доиенит Криминалистиччко-йоличијски универзииеети, Беогррад bojan.jankovic@kpu.edu.rs

\section{Улога редарске службе на спортским приредбама у Републици Србији}

Сажжейак: Традиционално схвайање да је само йоличија одг̄оворна за безбедносии на сиорииским ирриредбама увелико се найушйа, у смислу да редарска служба има све значајније месйо. То је йрейознатио и у законским ироииссима Србије, у нормама Закону о иривайном обезбеђењу (ЗПО), Законуо сирречавању насиља и недоличног̄ йонащања на сииорииским ириредбама (ЗСНСП), Закону о јавном окуйьљању, као и међународним ирройисима сйорйских савеза. Дефинисаюу улог̄е редарске службе доиринела је и нова Конвениија Савет̄а

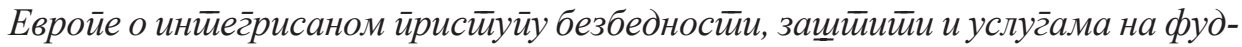
балским уйакмииама и друг̄им сйорйским дог̄ађајима (ЦЕТС 218), заједно са Прейоруком REC (2015) 1, и њеним анексима, која замењује све йрейходне иррейоруке, резолуције и изјаве. Прейорука је йосйала сасйавни део нове Конвенције (ЦЕТС 218). Заједничко за све йоменуйе йройисе је да се редарском службом могуу бавийи лица која су заврщила йосебну обуку. За разлику од међународних йройиса који йредвиђају обимну обуку за редаре, йосйојећи ирогррами у Србији ирредвиђају веома мали број часова. Раду редара свакако би йомог̄ло и йобољщиаье иојединих законских йройиса који регуулищу ову области. Рейублика Србија јощ није йоййисник Конвенције (ЦЕТС 218), йе је неойходно да државни орг̄ани иррисииуйе њеном йойиисиваюу и райификаиији како би Србија щито йре усвојила ново устиановљене евройске стиандарде у овој областии.

Кључне речи: редарска служба, сйорӣске ӣриредбе, Рейублика Србија

Датум пријема рада: 8.10.2019. 